\title{
Peran Identitas Agama Terhadap Niat Menggunakan Kosmetik Halal: Perluasan Theory of Planned Behavior
}

\author{
Anton Priyo Nugroho' ${ }^{*}$, Dzulfikar Izzat ${ }^{2}$, Wuri Suhasti ${ }^{3}$ \\ ${ }^{1}$ Magister Ilmu Agama Islam, FIAI, Universitas Islam Indonesia \\ ${ }^{2}$ Fakultas Ekonomi, Universitas Islam Indonesia \\ ${ }^{3}$ Prodi Perbankan Syariah, STEI Yogyakarta \\ * e-mail: priyo.nugroho@uii.ac.id
}

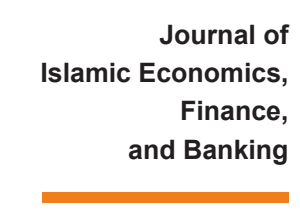

Vol. 2, No. 2, Desember 2019 , pp. 89-106, ISSN p:2622-4755 e:2622-4798

\section{Abstract}

Market share of halal cosmetics in Indonesia increased all of the time. It was not surprising, as a country with the biggest Moslem population in the world, the need of halal cosmetics is a must. Had it trued that the consumption of halal cosmetics driven by religion (Islam) as a social identity or by other factors. This study tried to find the role of religion as consumer's social identity with extended theory planned behavior. This study used purposived sampling technics among 100 collage students in Yogyakarta and analyzed with partial Least Square (PLS) $s$-SEM used smartPLS software. This research found that religion identity was not influenced toward intention to use cosmetics halal. The other variables, attitude, subjective norm and perceived behavior control have a positive and significant influenced toward intention to use halal cosmetics.

Keywords: Religion Identity, Halal Cosmetics, TPB

\section{Abstrak}

Market share kosmetik halal di Indonesia, selalu meningkat sepanjang waktu. Hal tersebut tentu saja bukan hal yang mengejutkan, sebagai negara dengan populasi umat islam terbesar didunia kebutuhan kosmetik halal merupakan suatu keniscayaan. Akan tetapi apakah benar bahwa konsumsi kosmetik halal tersebut didorong oleh agama (Islam) sebagai identitas sosial konsumen atau justru oleh faktor lain. Penelitian ini mencoba melihat peran agama sebagai identitas sosial konsumen, dengan menggunakan theory planned behavior. Penelitian ini merupakan penelitian kuantitatif, dengan teknik sampling purposive dengan jumlah angket sebanyak 100 responden mahasiswi yang beragama Islam di Yogyakarta. Data kemudian diolah dengan Partial Least Square (PLS)-SEM menggunakan software smartPLS.

Penelitian menemukan bahwa, identitas agama tidak memiliki peran terhadap niat menggunakan kosmetik halal. Sedangkan sikap, norma subyektif serta perceived behavior control memiliki pengaruh positif dan signifikan terhadap niat menggunakan kosmetik halal, namun pengaruh tersebut termasuk lemah.

Kata Kunci : Identitas Agama, Kosmetik Halal, TPB

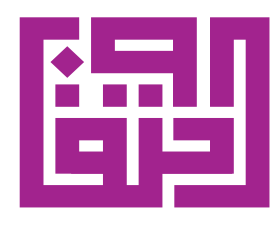

IHTIFAZ

Kampus 4 Universitas Ahmad Dahlan Jl. Ringroad Selatan, Tamanan Yanguntapan, Bantul Yogyakarta 55191 


\section{PENDAHULUAN}

Halal merupakan syarat mutlak yang harus terpenuhi dalam IHTIFAZ - JIEFB setiap produk yang akan dikonsumsi oleh umat Islam. Allah telah memerintahkan untuk memakan makanan yang halal dan baik sebagaimana terdapat dalam surat Al Baqarah (2) ayat 168. Perintah ini tidak hanya untuk sesuatu yang dimakan saja namun lebih luas termasuk segala sesuatu yang kita konsumsi (baca digunakan) harus halal, termasuk kosmetik.

Kosmetik halal merupakan produk kosmetik yang tidak boleh mengandung unsur babi, anjing, serta alkohol. Namun demikian halal lebih dari sekedar kandungan kosmetik saja, kosmetik halal harus dipandang sebagai sesuatu yang holistik, meliputi pembuatan, pengepakan termasuk distribusinya tidak boleh mengandung material yang berbahaya baik bagi manusia maupun lingkungan tidak menyakiti hewan dsb. Mengkonsumsi atau menggunakan kosmetik non halal berarti melanggar larangan agama Islam. Konsumen muslim harus selektif dalam memilih kosmetik yang akan digunakan, kosmerik harus halal dan thayib.

Produk yang lolos uji halal, akan mendapatkan sertifikasi halal dari LPPOM MUI. LPPOM MUI (Lembaga Pengkajian Pangan, Obat-obatan, dan Kosmetika Majelis Ulama Indonesia) merupakan lembaga yang bertugas untuk untuk meneliti, mengkaji, Robat-obatan dan produk kosmetika apakah aman dikonsumsi baik dari sisi kesehatan maupun terpenuhinya syariat Islam yakni halal atau boleh dan baik untuk dikonsumsi. Produk yang mendapatkan sertifikasi halal dari MUI, akan memudahkan konsumen ketika membeli kosmetik. Namun harus disadari bahwa belum semua kosmetik yang beredar di indonesia memiliki sertifikasi halal. Sekalipun begitu, pasar kosmetik halal di Indonesia semakin meningkat dari tahun ketahun ${ }^{1}$ yang berarti kesadaran untuk menggunakan kosmetik halal semakin meningkat. Meningkatnya pengunaan kosmetik halal didorong oleh beberapa faktor antara lain pengaruh lingkungan, kecocokan, kesadaran agama dan lain-lain.

Banyak penelitian yang membuktikan adanya pengaruh agama terhadap perilaku seperti Jaggi \& Xin (Jaggi \& Xin, 2017), Ahmad, Rahman \& Rahman (Ahmad, Rahman, \& Ab Rahman, 2015), Muhamad \& Mizerki (Muhamad \& Mizerski, 2010), Berger (Berger, 2006), Khraim, Khraim, Al-Kaidah, \& Al-Qurashi (Khraim, Khraim, Al-Kaidah, \& AlQurashi, 2011), Mansori (Mansori, 2012), Nugroho dkk. (Nugroho, Hidayat, \& Kusuma, 2017) dll. Namun demikian penelitian-penelitian diatas memandang agama sebagai kontruk religiusitas., bukan digunakan sebagai salah satu dimensi pembentuk identitas sosial. Oleh karena itu

\footnotetext{
1 Menurut laporan Thomson Reuters tahun 2018, total belanja kosmetik muslimah secara global tahun 2017 diperkirakan sebesar 61 milyar dollar, dan diperkirakan menjadi sekitar 90 milyar dollar pada tahun 2023, dengan rata-rata pertumbuhan $7 \%$. Pasar kosmetik halal di Indonesia tahun 2018 diperkirakan sebesar 3,9 milyar dollar, peringkat 2 dibawah India, diatas Rusia dan Turki (Thomson Reuters, 2018).
} 
penelitian ini mencoba melakukan kontruksi agama sebagai bagian dari identitas sosial dengan memperluas Theory of Planned Behavior (TPB).

TPB merupakan teori yang banyak digunakan dalam penelitianpenelitian mengenai perilaku individu (I. Ajzen, 1991). Hal ini disebabkan TPB merupakan model yang terintegrasi yang terdiri dari empat prediktor dari perilaku yaitu, sikap, norma subyektif, Perceived Behavioral Control $(P B C)$, dan niat untuk berperilaku (Icek Ajzen \& Driver, 1991). Ajzen mengatakan bahwa TPB bukan merupakan model yang ekslusif untuk memprediksi niat ataupun perilaku, TPB fleksibel untuk diperluas dengan memasukkan prediktor tambahan yang dapat menjelaskan secara signifikan varian dari niat (Icek Ajzen, 1991). Beberapa peneliti kemudian melakukan perluasan terhadap TPB, salah satu yang paling awal adalah Taylor dan Todd. Mereka mengatakan bahwa TPB tidak mengikut sertakan variabel seperti kebiasaan, kewajiban moral dan identitas diri yang mungkin saja memprediksi niat berperilaku secara lebih baik (Taylor \& Todd, 1995). Dengan melihat latar belakang diatas, maka penelitian ini mencoba memperluas TPB dengan menambah prediktor identitas agama dan digunakan untuk memprediksi niat menggunakan kosmetik halal.

\section{Teori dan Pengembangan Model Penelitian}

Theory of Planned Behavior merupakan teori yang dikembangkan dari Theory of Reason Action (TRA). TPB dikembangkan dari TRA karena ketidak mampuan TRA untuk memprediksi perilaku yang tidak sepenuhnya dibawah kontrol individu (Lemmens, Valkenburg, \& Peter, 2011). Pada akhirnya TPB menjadi teori yang sangat populer dan banyak digunakan untuk melakukan penelitian-penelitian perilaku yang tidak sepenuhnya dibawah kendali individu (Kaiser \& Gutscher, 2003). TPB tersusun atas tiga variabel independen, yaitu sikap, norma subyektif, dan percieved behavioral control, yang digunakan untuk memprediksi niat berperilaku.

\section{Niat Perilaku}

Ajzen dan Fishbein berpendapat bahwa individu cenderung untuk melakukan perilaku jika memiliki kesempatan; semakin kuat intensi atau niat untuk melakukan perilaku, semakin besar kemungkinan individu tersebut akan melakukan perilaku (Icek Ajzen \& Fishbein, 2000). Hal ini berarti bahwa semakin besar niat individu untuk terlibat dalam perilaku tertentu maka semakin besar kemungkinan perilaku tersebut akan ditampilkan. Mereka mengatakan bahawa relasi antara niat dengan perilaku telah banyak dibuktikan dalam penelitian-penelitian ekperimen, dimana niat berperilaku merupakan prediksi atas perilaku dimasa depan. Karena perilaku aktual dapat diprediksi dari niatnya, tidak heran sebagian besar penelitian mengenai perilaku lebih banyak meneliti niat berperilaku dibandingkan dengan perilaku aktualnya. 


\section{Identitas Agama}

Identitas merupakan konsep subyektif bagaimana seorang individu IHTIFAZ - JIEFB memandang diri mereka sendiri (Vignoles, Regalia, Manzi, Golledge, \& Scabini, 2006). Identitas sosial yaitu anggapan kelompok sebagai orang yang sama yang saling mengidentifikasi satu sama lain, melihat diri sendiri satu sama lain dengan cara yang sama (dalam satu kelompok) yang berbeda dengan anggota diluar kelompok. Penelitian Deaux, Reid, Mizrahi, \& Ethier (1995) menemukan lima jenis identitas sosial yaitu, relationship, vocational role, political afffiliation, stigmatized identity, dan terakhir agama (Deaux, Reid, Mizrahi, \& Ethier, 1995) . Dengan demikian identitas agama merupakan bagian dari kontruksi identitas sosial. Identitas agama berarti individu dalam satu kelompok mengidentifikasi diri sendiri sebagai penganut kepercayaan yang sama, memiliki nilai-nilai dan norma yang sama dalam satu kelompoknya yang berbeda dengan kelompok yang lain. Dengan melakukan perbandingan sosial, individu yang memiliki kesamaaan atribut dengan kelompoknya dianggap menjadi anggota kelompoknya sedankan individu yang memililiki perbedaan atribut dengan kelompoknya dianggap bukan sebagai bagian dari kelompok.

Dengan demikikian menurut Teori identitas sosial ini, menjadi bagian dari sebuah kelompok merupakan hal yang sangat penting bagi identitas individu, karena hal tersebut membantu mendefinisikan siapa mereka dan meningkatkan self-esteem dan kebahagiaan. Identitas agama merupakan salah satu dimensi dari identitas sosial, khususnya pada keanggotaan terhadap suatu kelompok agama yang berkaitan dengan konsep diri seseorang. Sehingga berdasar konsep identitas sosial ini, individu akan melakukan berbagai upaya untuk memperlihatkan identitasnya sebagai pemeluk suatu agama (Coşgel \& Minkler, 2004). Hal tersebut terjadi karena agama menyediakan kepercayaan dan nilai-nilai sebagai pedoman dalam berperilaku (Delener, 1994). Kepercayaan dan nilai-nilai agama tersebut akan mempengaruhi cara hidup seseorang, pilihan atas apa yang akan mereka lakukan, apa yang akan mereka konsumsi dan dengan siapa mereka bergaul. individu yang merasa menjadi bagian dari kelompok agama tertentu akan berusaha membeli dan menggunakan produk yang sejalan dengan agama sebagai identitas sosialnya. Seperti seorang wanita muslim mengenakan jilbab untuk menutupi rambutnya, seorang pemeluk katolik mengenakan kalung dengan salib, dan seorang yahudi yang mengenakan yarmulke atau sejenis kopiah yang terdapat lambang keyakinan yang dianutnya (Coşgel \& Minkler, 2004). Hal itu terjadi karena pilihan atas produk yang akan dikonsumsi membantu untuk mengidentifikasi dan menyampaikan identitas agama seseorang (Coşgel \& Minkler, 2004).

Agama akan mempengaruhi perilaku individu melalui dua sumber: pertama agama menetapkan aturan dan kewajiban termasuk juga sangsi yang secara langsung mengontrol perilaku individu. Sebagai contoh dalam agama Islam adanya pengharaman/larangan berjudi dan 
minum khamr (minuman keras), mengenakan jilbab (menutup aurat) bagi wanita, adanya larangan terhadap riba. Kedua, sebagai institusi sosial yang berpengaruh, agama memiliki peran yang tidak langsung terhadap terbentuknya budaya, norma, sikap dan nilai-nilai yang dianut dalam suatu masyarakat (Rackley, 2015).

Tidak mengherankan banyak penelitian yang menemukan hubungan antara agama dengan perilaku konsumen. Fam, Weller, dan Erdogan (2004) melakukan penelitian mengenai hubungan agama dengan iklan produk kontroversial di enam negara. Dalam penelitiannya ditemukan hubungan positif antara agama dengan iklan produk kontroversial (Fam, Waller, \& Erdogan, 2004). Penelitian Kamaruddin di Thailand dan Malaysia menemukan pengaruh positif antara agama dengan orientasi belanja (Muhamad Jantan \& Abdul Razak Kamarudin, 1999). Kemudian Soesilowati (2010) dalam penelitiannya mengenai perilaku konsumen muslim terhadap makanan halal di Indonesia, menemukan fakta bahwa agama berhubungan dengan konsumsi makanan halal. Semakin tinggi religiusitas seseorang maka semakin tinggi perhatiannya terhadap konsumsi makanan halal (Soesilowati, 2011). Kemudian Nugroho dkk., menemukan hubungan positif agama dengan perilaku menabung (Nugroho et al., 2017). Penelitian lainnya di China membuktikan ada hubungan yang positif dan signifikan antara agama dengan penyebaran inovasi (Azam, Fu, Abdullah, \& Abbas, 2011). Flogel dalam penelitiannya di Inggris, menemukan adanya hubungan positif antara identitas agama dengan perilaku memilih toko daging halal dikalangan komunitas muslim asia selatan (Bri, 2011). Namun beberapa penelitian menemukan hasil yang berbeda seperti penelitian Lau, Choe dan Tan di Malaysia, dalam penelitiannya mereka menemukan bahwa agama (mereka menyebutnya religius ektrinsik) ternyata tidak memiliki hubungan signifikan dengan perilaku konsumen (Lau, Choe, \& Tan, 2011). Melalui penelitian ekperimennya Benjamin, Choi \& Fisher menemukan bahwa identitas agama tidak berkaitan perilaku ekonomi (Benjamin, Choi, \& Fisher, 2010). Berdasar deskripsi diatas hipotesis yang dikemukakan adalah sbb :

$\mathrm{H} 1$ :Identitas agama berpengaruh positif terhadap niat menggunakan kosmetik halal

\section{Sikap}

Sikap secara umum merupakan evaluasi atas obyek psikologi berupa baik buruk, senang tidak senang (Icek Ajzen, 2001). Menurutnya sikap merupakan kecenderungan kognitif, afektif, dan konatif yang dipelajari individu untuk melakukan respon secara positif maupun negatif terhadap objek, situasi, institusi, konsep atau seseorang. Oleh karena sikap merupakan sesuatu yang dipelajari oleh individu, maka sikap bukanlah perilaku, melainkan suatu disposisi mengenai perilaku tertentu, sikap mengimplikasikan hubungan seseorang dengan obyek yang tidak bersifat netral namun berupa positif-negatif, suka-tidak suka, senang- 
tidak senang dan sebagainya (Icek Ajzen \& Fishbein, 1977). Karena sikap merupakan antecedent dari perilaku, maka sebelum konsumen (berperilaku) menggunakan kosmetik halal, terlebih dahulu muncul sikap konsumen tersebut terhadap kosmetik halal.

Beberapa penelitian membuktikan hubungan yang positif antara sikap dengan perilaku. Shih dan Fang melakukan perluasan model TPB untuk memprediksi penggunaan internet banking di Taiwan, menemukan adanya hubungan positif dan signifikan antara sikap dengan niat perilaku (Shih \& Fang, 2004). Penelitiannya berhasil membuktikan model TPB yang dikembangkan berhasil memprediksi perilaku lebih baik dibandingkan model TPB awal. Penelitian Xiao dan Wu menemukan adanya hubungan positif dan signifikan antara sikap dengan perilaku (27). Beberapa penelitian lain seperti Amin dan Ramayah (Amin \& Ramayah, 2010);Pokulanagara \& Natesan (Pookulangara \& Natesan, 2010); Paul, Modi \& Patel (Paul, Modi, \& Patel, 2016) menemukan hal yang tidak berbeda. Namun dalam penelitian mengenai produk halal di Malaysia, Azmi Abd Aziz menemukan bahwa pengaruh sikap tidak signifikan terhadap niat perilaku (Azmi Abd Aziz, 2007). Berdasar deskripsi diatas ditemukan bahwa ada hubungan positif antara sikap konsumen terhadap produk kosmetik halal dengan niat perilaku untuk menggunakan kosmetik halal. Oleh karena itu hipotesis yang diajukan adalah :

H2 : Sikap konsumen berpengaruh positif terhadap niat menggunakan kosmetik halal.

\section{Norma Subyektif}

Norma subjektif menurut Fishbein dan Azjen (1975) merupakan faktor dari luar individu yang berupa persepsi seseorang mengenai orang lain untuk menyetujui atau tidak menyetujui suatu perilaku tertentu (Icek Ajzen \& Fishbein, 1977). Menurutnya norma subyektif ini, merupakan dorongan sosial yang menyebabkan seseorang untuk melakukan atau tidak melakukan perilaku tertentu. Oleh karena itu individu cenderung akan membentuk perilaku sesuai dengan norma yang dianut oleh lingkungan sosialnya. Seseorang akan melakukan perilaku tertentu jika memperoleh dorongan dari orang-orang yang dianggap penting baginya. Oleh karena itu dorongan atau pengaruh orang lain merupakan salah satu determinan dari perilaku individu. Jika teman dilingkungan pergaulan mengatakan hal-hal yang baik mengenai kosmetik halal, maka hal tersebut akan mendorong individu untuk berniat melakukan perilaku tertentu. Hal sebaliknya jika seseorang mendapat tanggapan negatif mengenai kosmetik halal dari teman disekitarnya akan menyebabkan individu tersebut akan mengurungkan niatnya menggunakan kosmetik halal.

Banyak penelitian membuktikan relasi antara norma subyektif dengan niat perilaku. Penelitian Majali dan Nik Mat di Jordan menemukan 
hubungan yang positif antara norma subyektif dengan niat perilaku (Mohamad, Building, \& Ismail, 2010), demikian juga beberapa penelitian yang lain seperti Tsairidis \& Grigoriadis (Maditinos, Tsairidis, \& Grigoriadis, 2009), Khalek, Hayati \& Ismail (Khalek, Hayaati, \& Ismail, 2015) menemukan hal yang kurang lebih sama. Sedikit berbeda, penelitian di Jepang mengenai ebook reader yang terhubung ke jaringan menemukan bahwa pengaruh sosial ini justru memiliki pengaruh negatif

Journal of Islamic Economics, Finance, and Banking

Vol. 2, No. 2, Desember 2019. pp. 89-106, ISSN p:2622-4755 e:2622-4798 terhadap niat membeli ebook reader (Koeder, Mohammed, \& Sugai, 2011), demikian juga hasil penelitian Hsiu Fen Lin di Taiwan menemukan bahwa norma subyektif tidak signifikan terhadap niat perilaku berbelanja online (Lin, 2007). Penelitian Paul, Modi \& Patel menemukan norma subyektif tidak berpengaruh terhadap niat menggunakan produk ramah lingkungan (Paul et al., 2016). Oleh karena itu berdasar deskripsi diatas, dapat disimpulkan adanya hubungan positif antara norma subyektif dengan niat menggunakan kosmetik halal. Oleh karena itu hipotesis yang diajukan adalah sbb :

H3 : Norma subyektif berpengaruh positif terhadap niat menggunakan kosmetik halal.

\section{Perceived Behavioral Control}

Perceived Behavioral Control atau disebut kontrol perilaku menggambarkan tentang persepsi kemampuan diri individu dalam melakukan suatu perilaku. Sebagai prediktor dari perilaku, percieved behavioral control (PBC), menggunakan asumsi jika niat berperilaku itu konstan, maka perilaku yang controlable akan cenderung muncul dibandingkan dengan perilaku yang kurang controllable (Armitage \& Christian, 2003). Ajzen menjelaskan bahwa perilaku seseorang tidak hanya dikendalikan oleh dirinya sendiri, tetapi juga membutuhkan kontrol, misalnya berupa ketersediaan sumber daya dan kesempatan bahkan keterampilan tertentu (Icek Ajzen, 2005). Oleh karena itu Ajzen mengatakan bahwa PBC ini, mencerminkan dimensi kesulitan yang diterima (percieved difficulty/mudah atau sulitnya untuk melakukan perilaku tertentu) dan controlability (sejauh mana melakukan suatu perilaku itu tergantung pada individu itu sendiri). Jika individu menganggap menggunakan kosmetik halal itu sesuatu yang mudah dan menyenangkan, maka individu tersebut akan menggunakannya. Sebaliknya jika menggunakan kosmetik halal merupakan sesuatu yang menyulitkan dirinya maka individu tersebut tidak akan mengunakannya. Banyak penelitian yang membuktikan pengaruh positif PBC terhadap niat berperilaku maupun terhadap perilaku aktual seperti Khalek, Hayati \& Ismail (Khalek et al., 2015), Alleyne \& Broome (Alleyne \& Broome, 2011), Beiginia dkk. (Beiginia, Besheli, Soluklu, \& Ahmadi, 2011), Bamberg, Ajzen \& Schmidt (Bamberg, Ajzen, \& Schmidt, 2003). Oleh karena itu hipotesis yang dikemukan adalah :

H4 :Perceived Behavior Control berpengaruh positif terhadap niat menggunakan kosmetik halal. 
Berdasar deksripsi diatas maka model penelitian ini adalah sebagai berikut :

IHTIFAZ - JIEFB

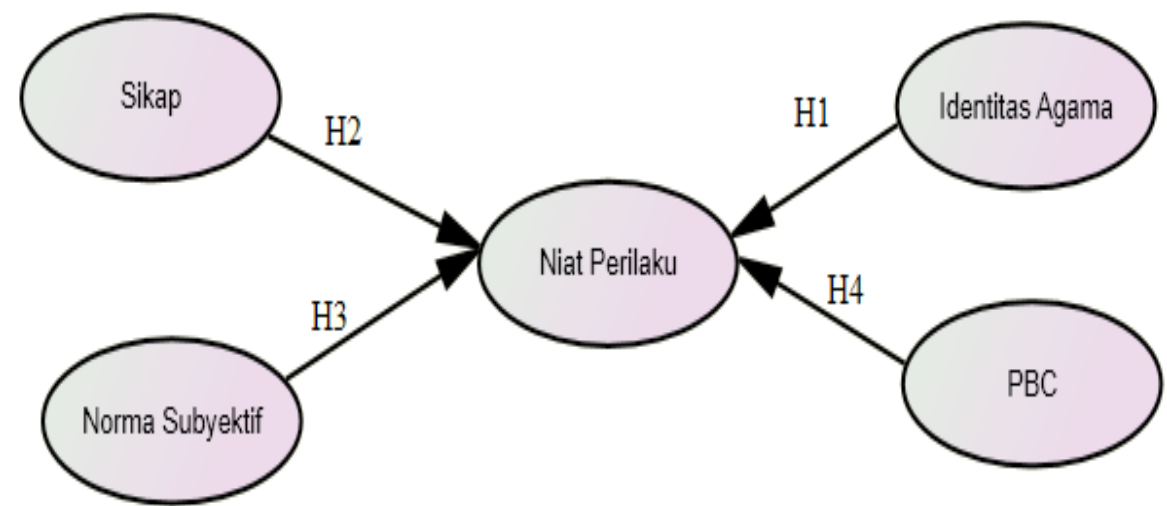

Gambar 1. Model Penelitian

\section{METODE PENELITIAN}

Penelitian ini menggunakan metode survey terhadap 125 orang responden, namun dari angket yang lengkap dan dapat digunakan untuk analisis lanjutan hanya sebanyak 100 orang. Unit analisis yang digunakan adalah individu mahasiswi pengguna kosmetik untuk keperluan sendiri. Sampel diambil dengan teknik purposive sampling, dari mahasiswi berbagai perguruan tinggi di Yogyakarta yang beragama Islam.

Pengukuran sikap dilakukan secara langsung (direct measurement), dan dikembangkan dari skala pengukuran yang dilakukan oleh Ajzen (2010) yang terdiri dari tiga item pertanyan. Pengukuran norma subyektif dilakukan secara langsung dan dikembangkan berdasar skala pengukuran yang digunakan oleh Maditinos, dkk. yang terdiri dari empat item pertanyaan (Keisidou, Sarigiannidis, \& Maditinos, 2011). Perceived behavior control diukur secara langsung dengan menggunakan tiga item pertanyaan yang dikembangkan dari Ajzen (2010). Niat menggunakan kosmetik halal diukur secara langsung dan dikembangkan berdasar skala yang digunakan oleh Nugroho, dkk.(Nugroho et al., 2017) yang terdiri dari dua item pertanyaan. Pengukuran identitas agama dikembangkan berdasar skala yang digunakan oleh Alwin, Felson, Falker \& Tufis (2006), yang terdiri dari sembilan item pertanyaan (Alwin, Felson, Walker, \& Tufiş, 2006). Penelitian ini, menggunakan jawaban berjenis continuous rating scale yang merupakan merupakan skala rasio. Dengan skala berjenis rasio maka semua operasi aritmatika dapat dilakukan termasuk ketika menggunakan analisis PLS-SEM, yang membutuhkan prasyarat data dengan skala interval atau rasio. Continuous rating scale merupakan skala dengan dua alternatif jawaban yang saling bertolak belakang atau bipolar, misalnya tidak setuju dengan sangat setuju, tidak yakin dengan sangat yakin, senang dengan sedih dsb. Skala bipolar merupakan skala yang tepat untuk digunakan pada penelitian sikap dan perilaku. Data 
selanjutnya dianalisis dengan statistik deskriftif serta variance based structural equation modelling atau lebih dikenal dengan PLS-SEM.

\section{HASIL PENELITIAN DAN PEMBAHASAN}

Responden $70 \%$ berasal dari PT ke-Islam-an dan $30 \%$ berasal dari PT umum di Yogyakarta. Sebagian besar (67 \% ) sudah menginjak semester 5 keatas, hanya sebagian kecil (33\%') yang baru menempuh semester 2 sampai 4. Dari 100 orang responden, 65 mahasiswi merupakan pengguna kosmetik halal preparat make up wajah, sedangkan sebanyak $26 \%$ merupakan pengguna kosmetik halal preparat kulit, sisanya pengguna preparat mata dll. Sebagian besar merupakan pengguna loyal dari kosmetik halal, terbukti mahasiswi yang merupakan pengguna kosmetik halal selama 2-3 tahun ada sebanyak $47 \%$ dan $24 \%$ menggunakan kosmetik halal lebih dari 3 tahun. Hanya sebagian kecil merupakan pengguna baru (kurang dari 1 tahun), yaitu sebesar $29 \%$.

\section{Hasil Uji Model Pengukuran}

Dalam analisis SEM terdapat dua jenis analisis yaitu analisis model pengukuran dan analisis model struktural (Hair, Hult, Ringle, \& Sarstedt, 2014). Model pengukuran adalah model yang menilai kelayakan instrument sebagai alat ukur penelitian (Haenlein \& Kaplan, 2004), (Vinzi, Chin, \& Henseler, 2010) atau lebih dikenal dengan uji validitas dan reliabilitas instrument. Model pengukuran yang diuji ditampilkan seperti gambar dibawah ini.

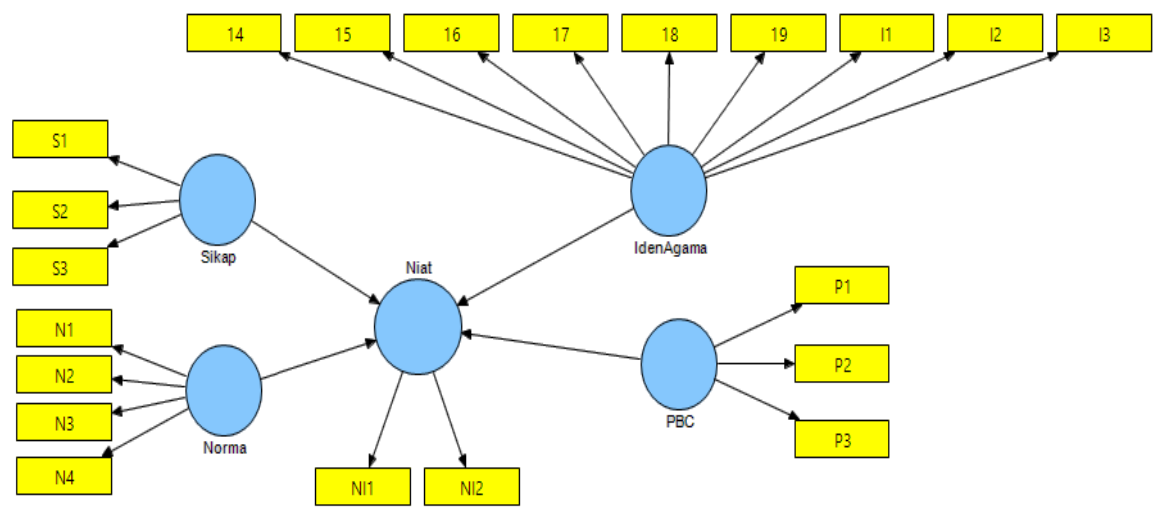

Gambar 2. Model Pengukuran

Hasil output smartpls menunjukkan empat indikator yang bermasalah dengan validitas konvergen yaitu 1 indikator $\operatorname{PBC}(0,172)$, adan tiga indikator identitas agama masing-masing memiliki nilai faktor loading sebesar 0,366; 0,330 dan 0,414. Ke empat indikator tersebut memiliki nilai faktor loading dibawah 0,4 dan AVE dibawah 0,5 sehingga langsung dihapus (Hair et al., 2014). Hasil analis ulang 
menujukkan semua indikator memiliki faktor loading diatas 0,7 dan AVE $>0,5$ sehingga dapat dikatakan semua variabel memenuhi syarat IHTIFAZ - JIEFB validitas konvergen. Selanjutnya berdasar kriteria Fornell-Larcker, hasil uji validitas diskriminan menunjukkan VAVE > korelasi antar kontruk, sehingga validitas diskriminan terpenuhi (Hair et al., 2014). Selanjutnya angket memiliki skor reliabilitas yang baik yang ditunjukkan oleh nilai Cronbacch alpha $>0,6$ dan reliabilitas komposite $>0,6$ (Hair et al., 2014). Hasil uji validitas dan reliabilitas selengkapnya dapat dilihat pada tabel outer model dan korelasi antar kontruk

Tabel 1. Outer Model

\begin{tabular}{crrcrr}
\hline & AVE & $\begin{array}{c}\text { Composite } \\
\text { Reliability }\end{array}$ & R Square & $\begin{array}{c}\text { Cronbachs } \\
\text { Alpha }\end{array}$ & Redudancy \\
\hline IdenAgama & 0.5192 & 0.8651 & & 0.8203 & \\
Niat & 0.9183 & 0.9274 & 0.4981 & 0.9112 & 0.0733 \\
Norma & 0.6012 & 0.8541 & & 0.7788 & \\
PBC & 0.611 & 0.7453 & & 0.6505 & \\
Sikap & 0.744 & 0.897 & & 0.8275 & \\
\hline
\end{tabular}

Sumber : output SmartPLS (2019)

Tabel 2. Korelasi Antar Kontruk

\begin{tabular}{crrrrr}
\hline & \multicolumn{1}{l}{$\begin{array}{l}\text { Identitas } \\
\text { agama }\end{array}$} & \multicolumn{1}{c}{ Niat } & $\begin{array}{c}\text { Norma } \\
\text { subyektif }\end{array}$ & PBC & \multicolumn{1}{l}{ VAVE } \\
\hline Niat & 0.4031 & 1 & 0 & 0 & 0,958 \\
Norma & 0.3341 & 0.5778 & 1 & 0 & 0,775 \\
PBC & 0.3661 & 0.4582 & 0.3698 & 1 & 0,781 \\
Sikap & 0.3905 & 0.6138 & 0.5293 & 0.4647 & 0,862 \\
\hline
\end{tabular}

Sumber : output SmartPLS (2019)

\section{Hasil Uji Hipotesis}

Ada empat hipotesis yang diuji, hasil bootstrapping PLS dapat disimpulkan kedalam gambar model akhir dan tabel rangkuman uji hipotesis dibawah ini.

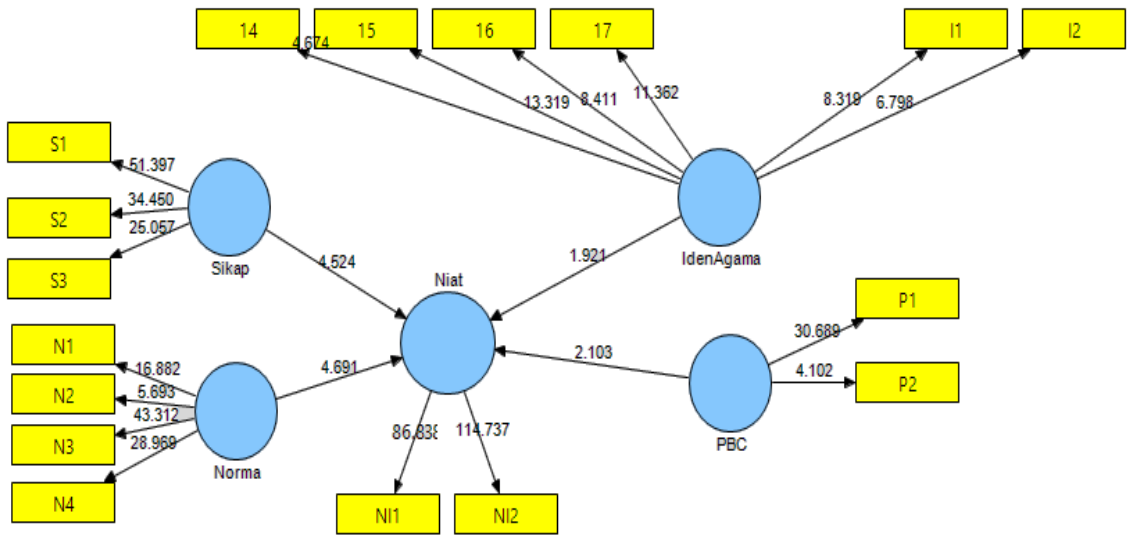

Sumber : output SmartPLS (2019) 
Tabel 3. Rangkuman Uji Hipotesis

\begin{tabular}{|c|c|c|c|c|}
\hline & Path Koefisien & T Statistics & Status & Finance, \\
\hline Identitas Agama -> Niat & 0.1152 & 1.9212 & $\begin{array}{r}\text { Tidak } \\
\text { signifikan }\end{array}$ & \\
\hline Norma -> Niat & 0.3061 & 4.6911 & Signifikan* & $\begin{array}{l}\text { Vol. 2, No. 2, Desember } 2019 \text {, } \\
\text { pp. 89-106, ISSN p:2622-4755 }\end{array}$ \\
\hline PBC -> Niat & 0.1451 & 2.1027 & Signifikan* & \\
\hline Sikap -> Niat & 0.3394 & 4.5235 & Signifikan* & \\
\hline
\end{tabular}

*Signifikan pada $\mathrm{a}=0,05 \mathrm{t}=1,96$

Sumber : output SmartPLS (2019)

Pengaruh identitas agama ke niat perilaku (t statistik $=1,9212$ ) < (ta0,05=1,96) yang berarti H0 diterima dengan kata lain hipotesis 1 yang diajukan ditolak atau tidak terbukti berdasarkan data empiris ada pengaruh identitas agama terhadap niat menggunakan kosmetik halal. Sikap berpengaruh positif dan signifikan terhadap niat menggunakan kosmetik halal yang ditunjukkan dengan nilai t statistik $(4,5235)>$ nilai t a 0,05 (1,96). Dengan demikian hipotesis 2 yang berbunyi " sikap memiliki pengaruh positif dan signifikan terhadap niat menggunakan kosmetik halal" didukung oleh data empiris. Norma subyektif memiliki pengaruh positif dan signifikan terhadap niat menggunakan kosmetik halal terbukti dari (t statistik 4,6911) $>($ ta $0,05=1,96)$. Dengan demikian hipotesis 3 yang diajukan diterima dan didukung data empiris. Terakhir, terdapat pengaruh positif dan signifikan perceived behavior control terhadap niat berperilaku terbukti dari nilai t statistik $(2,1027)>$ nilai t a $0,05(1,96)$.

\section{PEMBAHASAN}

\section{Pengaruh Identitas Agama Terhadap Niat Menggunakan Kosmetik Halal}

Agama sebagai identitas sosial ternyata tidak mempengaruhi konsumen untuk menggunakan kosmetik halal. Temuan ini sebetulnya bukan sesuatu yang mengejutkan. Konsumen Indonesia (baca masyarakat jawa sejak dahulu sebagian dikenal sebagai masyarakat abangan (Clifford, 1983) yaitu masyarakat yang beragama islam namun tidak konsekuen menjalankan ajaran agamanya dengan benar. Penelitian Geertz yang dilakukan tahun 1950-an tersebut tampaknya masih relevan dengan kondisi terkini. Agama hanya sebatas ritual saja, sebatas doktrin, namun tidak dijalankan secara kaffah dalam seluruh aspek kehidupan. Agama tidak dianggap sebagai bagian dari identitas, akibatnya niat menggunakan kosmetik halal tidak didorong oleh kesamaan identitas namun disebabkan oleh faktor lain yang dianggap lebih penting. Temuan 
ini menguatkan hasil penelitian Nugroho, dkk. (Nugroho et al., 2017), Mostafa (Mohamed M. Mostafa, 2019) yang menemukan adanya IHTIFAZ - JIEFB ketidak konsistenan antara agama dengan perilaku masyarakat. Dalam penelitiannya, mereka menemukan bahwa skor religious responden tinggi, namun hal tersebut tidak konsisten dengan perilaku responden. Responden masih menggunakan bank konvensional (Nugroho et al., 2017) atau tidak mengenakan baju muslim (Mohamed M. Mostafa, 2019). Berbeda dengan temuan Nuwairah, dkk. di Malaysia, yang menemukan pengaruh signifikan agama dengan perilaku menggunakan kosmetik halal, namun kurang sensitive jika dibandingkan dengan perilaku konsumsi makanan halal (Ahmad, Rahman, \& Rahman, 2015). Masyarakat (baca konsumen) tingkat kepedulian halalnya hanya untuk makanan saja, akibatnya kosmetik yang sifatnya tidak untuk dimakan menjadi kurang diperhatikan substansi halalnya.

\section{Pengaruh Sikap Terhadap Niat Menggunakan Kosmetik Halal}

Penelitian ini menemukan bahwa sikap merupakan prediktor yang paling domian dari niat menggunakan kosmetik halal. Namun demikian nilai estimasi parameter yang hanya sebesar 0,34 menunjukan hubungan yang positif namun lemah antara sikap dengan niat menggunakan kosmetik halal. Semakin baik sikap terhadap kosmetik halal maka niat untuk menggunakan kosmetik halal akan semakn kuat, demikian sebaliknya, semakin buruk sikap terhadap kosmetik halal maka semakin berkurang niat untuk menggunakan kosmetik halal. Temuan ini sejalan dengan penelitian-penelitian sebelumnya seperti Khalek, Hayaati, \& Ismail, (Khalek et al., 2015) dan Paul, Modi, \& Patel, (Paul et al., 2016).

\section{Pengaruh Norma Subyektif Terhadap Niat Menggunakan Kosmetik Halal}

Norma Subyektif merupakan satu faktor non psikologis dalam TPB. Sikap dan Percieved Behavior Control (PBC) merupakan faktor internal individu maka Norma subyektif ini merupakan faktor diluar individu yang diperkirakan menjadi antesedent dari niat berperilaku atau perilaku. Sebagian menyebut norma subyektif ini sebagai faktor sosial. Estimasi parameter norma subyektif terhadap niat menggunakan kosmetik halal sebesar 0,31 yang bermakna semakin kuat pengaruh norma subyektif maka semakin kuat pula niat untuk menggunakan kosmetik halal, dan sebaliknya semakin lemah pengaruh norma subyektif maka semakin lemah pula niat untuk menggunakan kosmetik halal. Norma subyektif merupakan antecedent niat menggunakan kosmetik halal yang terkuat nomor dua sesudah sikap. Hal ini berbeda dengan temuan penelitian Echchabi \& Aziz (Echchabi \& Aziz, 2012), Rahab (Rahab \& Wahyuni, 2013) dan Nugroho dkk. (Nugroho et al., 2017), dimana skor norma subyektif merupakan variabel dengan pengaruh paling kecil dan merupakan variable paling lemah. 


\section{Pengaruh Percieved Behavior Control (PBC) terhadap Niat Menggunakan Kosmetik Halal}

Nilai estimasi PBC terhadap niat menggunakan kosmetik halal besarnya separuh dari nilai estimasi norma subyektif terhadap niat menggunakan kosmetik halal $(0,14$ dibandingkan 0,30). Hal ini menujukkan bahwa pengaruh PBC terhadap niat menggunakan kosmetik halal lebih kecil dibandingkan pengaruh norma subyektif terhadap niat menggunakan kosmetik halal. Temuan ini berbeda dengan Bandura dan Sirgy, yang berpendapat bahwa Percieved Behavior Control merupakan motif internal yang kuat yang dianggap lebih penting dibandingkan dengan pengaruh sosial (Sirgy, 1982). Dalam kasus niat menggunakan kosmetik halal, ternyata peran PBC lebih lemah dibandingkan norma subyektif. Konsumen berniat menggunakan kosmetik halal, lebih banyak dipengaruhi oleh pengaruh sosial, teman dan lingkungan dimana dia berdomisili, dibandingkan dengan PBC. Temuan ini sejalan dengan penelitian Patel, dkk.(Paul et al., 2016), dan Khalek, dkk.(Khalek et al., 2015).

\section{KESIMPULAN DAN IMPLIKASI}

Penelitian ini menemukan bahwa TPB dapat digunakan untuk memprediksi niat menggunakan kosmetik halal. Identitas agama tidak memiliki pengaruh terhadap niat menggunakan kosmetik halal, hal ini menunjukkan bahwa konsumen menggunakan kosmetik halal didorong oleh faktor lain diluar identitas agama seperti kesesuaian dengan kulit, harga, merk dan faktor-faktor lain. Penggunaan kosmetik halal masih belum melekat sebagai sebuah representasi identitas agama konsumen secara umum. Tingkat kesadaran konsumen akan kosmetik halal masih rendah, lebih rendah dibandingkan kesadaran terhadap makanan halal (Ahmad, Rahman, \& Rahman, 2015). Sikap dan norma subyektif lebih dominan berperan terhadap niat menggunakan kosmetik halal, sehingga edukasi masyarakat tentang pentingnya kosmetik halal perlu digalakkan oleh pihak yang berkepentingan. Sebagai negara dengan prosentase penduduk muslim terbesar didunia, pemerintah perlu menerbitkan regulasi yang bersifat memaksa, mengenai kewajiban sertfikasi halal untuk kosmetik yang dijual di Indonesia. Dengan demikian, tanpa sadar konsumen akan membeli kosmetik halal, sekalipun kepeduliannya terhadap kosmetik halal rendah. Pemilihan brand ambassador yang tepat, pemasaran melalui komunitas juga menjadi faktor yang kunci dalam mendorong konsumen untuk menggunakan kosmetik halal.

\section{DAFTAR PUSTAKA}

Ahmad, A. N., Rahman, A. A., \& Ab Rahman, S. (2015). Assessing knowledge and religiosity on consumer behavior towards halal food and cosmetic products. International Journal of Social Science and Humanity, 5(1), 10.
Journal of Islamic Economics, Finance, and Banking

Vol. 2, No. 2, Desember 2019 , pp. 89-106, ISSN p:2622-4755 e:2622-4798

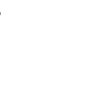


Ahmad, A. N., Rahman, A. A., \& Rahman, S. A. (2015). Assessing Knowledge and Religiosity on Consumer Behavior towards Halal IHTIFAZ - JIEFB Food and Cosmetic Products, 5(1), 10-14. https://doi.org/10.7763/ IJSSH.2015.V5.413

Ajzen, I. (1991). The theory of planned behavior. Organizational Behavior and Human Decision Processess, 50(2), 179-211.

Ajzen, Icek. (1991). The theory of planned behavior. Orgnizational Behavior and Human Decision Processes, 50, 179-211. https://doi. org/10.1016/0749-5978(91)90020-T

Ajzen, Icek. (2001). Nature and Operation of Attitudes. Annual Review of Psychology, 52(1), 27. https://doi.org/10.1146/annurev. psych.52.1.27

Ajzen, Icek. (2005). Attitudes, personality, and behavior. McGraw-Hill Education (UK).

Ajzen, Icek, \& Driver, B. L. (1991). Prediction of leisure participation from behavioral, normative, and control beliefs: An application of the theory of planned behavior. Leisure Sciences, 13(3), 185-204.

Ajzen, Icek, \& Fishbein, M. (1977). Attitude-behavior relations: A theoretical analysis and review of empirical research. Psychological Bulletin, 84(5), 888-918. https://doi.org/10.1037/00332909.84.5.888

Ajzen, Icek, \& Fishbein, M. (2000). Attitudes and the AttitudeBehavior Relation: Reasoned and Automatic Processes. European Review of Social Psychology, 11(1), 1-33. https://doi. org/10.1080/14792779943000116

Alleyne, P., \& Broome, T. (2011). Using the theory of planned behaviour and risk propensity to measure investment intentions among future investors. Journal of Eastern Caribbean Studies, 36(1), 1-20. Retrieved from http://www.econbiz.de/Record/using-the-theoryof-planned-behaviour-and-risk-propensity-to-measure-investmentintentions-among-future-investors-alleyne-philmore/10009308883

Alwin, D. F., Felson, J. L., Walker, E. T., \& Tufiş, P. A. (2006). Measuring religious identities in surveys. Public Opinion Quarterly, 70(4), 530-564.

Amin, H., \& Ramayah, T. (2010). SMS banking: Explaining the effects of attitude, social norms and perceived security and privacy. The Electronic Journal of Information Systems in Developing Countries, 41.

Armitage, C. J., \& Christian, J. (2003). From Attitudes to Behaviour: Basic and Applied Research on the Theory of Planned Behaviour. Current Psychology, 22(3), 187-195. https://doi.org/10.1007/ s12144-003-1015-5 
Azam, A., Fu, Q., Abdullah, I., \& Abbas, S. A. (2011). Impact of 5-D of Religiosity on Diffusion Rate of Innovation. International Journal of Business \& Social Science, 2(17), 177-185.

Azmi Abd Aziz, M. A. and Z. I. (2007). the Perception To Choose Halal Cosmetics Products: an Empirical Study for Malaysian Consumer, 1-10. https://doi.org/10.1017/CBO9781107415324.004

Bamberg, S., Ajzen, I., \& Schmidt, P. (2003). Choice of Travel Mode in

Vol. 2. No. 2, Desember 2019, pp. 89-106, ISSN p:2622-4755 the Theory of Planned Behavior: The Roles of Past Behavior, Habit, and Reasoned Action. Basic and Applied Social Psychology, 25(May), 175-187. https://doi.org/10.1207/S15324834BASP2503_01

Beiginia, A. R., Besheli, A. S., Soluklu, M. E., \& Ahmadi, M. (2011). Assessing the mobile banking adoption based on the decomposed theory of planned behaviour. European Journal of Economics, Finance and Administrative Sciences, 28(1), 7-15.

Benjamin, D. J., Choi, J. J., \& Fisher, G. W. (2010). Religious Identity and Economic Behavior. NBER, \#15925.

Berger, I. E. (2006). The influence of religion on philanthropy in Canada. Voluntas, 17(2), 110-127. https://doi.org/10.1007/s11266-0069007-3

Bri, S. A. (2011). FR A NZ FLÖGEL E thnic versus R eligious G rocery Shopping An I nves ti ga ti on into the Shopping place selec ti on of "South Asian Bri ti sh Muslims ", (1), 13-23.

Clifford, G. (1983). Abangan, Santri, Priyayi dalam masyarakat jawa. Pustaka. Jakarta.

Coşgel, M. M., \& Minkler, L. (2004). Religious identity and consumption. Review of Social Economy, 62(3), 339-350.

Deaux, K., Reid, A., Mizrahi, K., \& Ethier, K. A. (1995). Parameters of social identity. Journal of Personality and Social Psychology, 68(2), 280.

Delener, N. (1994). Religious contrasts in consumer decision behaviour patterns: their dimensions and marketing implications. European Journal of Marketing, 28(5), 36-53.

Echchabi, a, \& Aziz, H. (2012). the Relationship Between Religiosity and Customers'Adoption of Islamic Banking Services in Morocco. Contemporary Business Studies, 89-95. Retrieved from http://www. academia.edu/download/30870898/IJCBS_Vol_3_No_5_May_2012_ ISSN_2156-7506.pdf\#page $=25$

Fam, K. S., Waller, D. S., \& Erdogan, B. Z. (2004). The influence of religion on attitudes towards the advertising of controversial products. European Journal of Marketing, 38(5/6), 537-555. https:// doi.org/10.1108/03090560410529204

Haenlein, M., \& Kaplan, A. M. (2004). A Beginner's Guide to Partial Least Squares Analysis. Understanding Statistics, 3(4), 283-297. https:// doi.org/10.1207/s15328031us0304_4 
Hair, J. F. J., Hult, G. T. M., Ringle, C., \& Sarstedt, M. (2014). A Primer on Partial Least Squares Structural Equation Modeling (PLS-SEM). Long Range Planning (Vol. 46). https://doi.org/10.1016/j.Irp.2013.01.002

Jaggi, B., \& Xin, H. C. (2017). Impact of Religiosity on Auditors' Behavior and Audit Fees. Journal of Accounting, Ethics and Public Policy, 18(3).

Kaiser, F. G., \& Gutscher, H. (2003). The proposition of a general version of the theory of planned behavior: predicting ecological behavior1. Journal of Applied Social Psychology, 33(3), 586-603.

Keisidou, E., Sarigiannidis, L., \& Maditinos, D. (2011). Consumer characteristics and their effect on accepting online shopping, in the context of different product types. International Journal of Business Science and Applied Management, 6(2), 31-51.

Khalek, A. A., Hayaati, S., \& Ismail, S. (2015). Why Are We Eating Halal - Using the Theory of Planned Behavior in Predicting Halal Food Consumption among Generation $Y$ in Malaysia, 5(7). https://doi. org/10.7763/IJSSH.2015.V5.526

Khraim, H. S., Khraim, A. S., Al-Kaidah, F. M., \& Al-Qurashi, D. R. (2011). Jordanian Consumer's Evaluation of Retail Store Attributes: The Influence of Consumer Religiosity. International Journal of Marketing Studies, 3(4), 105. https://doi.org/10.5539/ijms.v3n4p105

Koeder, M. J., Mohammed, U., \& Sugai, P. (2011). Study of consumer attitudes towards connected reader devices in Japan based on the decomposed Theory of Planned Behavior. Economics \& Management Series, (May).

Lau, T.-C., Choe, K.-L., \& Tan, L.-P. (2011). Consumers' Ethical Beliefs: Ascertaining the Roles of Money and Religiosity. International Conference on Sociality and Economics Development, 10, 162-166.

Lemmens, J. S., Valkenburg, P. M., \& Peter, J. (2011). The Effects of Pathological Gaming on Aggressive Behavior. Journal of Youth and Adolescence, 40(1), 38-47. https://doi.org/10.1007/s10964-0109558-x

Lin, H. F. (2007). Predicting consumer intentions to shop online: An empirical test of competing theories. Electronic Commerce Research and Applications, 6(4), 433-442. https://doi.org/10.1016/j. elerap.2007.02.002

Maditinos, D., Tsairidis, C., \& Grigoriadis, C. (2009). Internet Banking user acceptance: Evidence from Greece and Bulgaria. 5 Th HSSS Conference, (June), 24-27. Retrieved from http://abd.teikav.edu. gr/articles/Maditinos_Tsairidis_Grigoriadis.pdf

Mansori, S. (2012). Impact of religion affiliation and religiosity on consumer innovativeness; the evidence of Malaysia. World Applied Sciences Journal, 17(3), 301-307. 
Mohamad, R., Building, A., \& Ismail, N. A. (2010). Journal of Internet Banking and Commerce. Journal of Internet Banking and Commerce, 15(1), 1-11. https://doi.org/10.1007/978-3-531-92534-9_12

Mohamed M. Mostafa, author. (2019). Profiling Kuwaiti female apparel consumers : Self-identity, social interactions, and prestige consumption. International Journal of Sociology and Social Policy VO - 39, (1/2), 98. https://doi.org/10.1108/IJSSP-06-2018-0109

Muhamad Jantan, \& Abdul Razak Kamarudin. (1999). Store Image and Store Choice Decision: An Investigation of Consumers' Shopping Behaviour in Malaysia. Asian Academy of Management Journal. Retrieved from http://web.usm.my/aamj/4.2.1999/4-2-5.pdf

Muhamad, N., \& Mizerski, D. (2010). The constructs mediating religions' influence on buyers and consumers. Journal of Islamic Marketing, 1(2), 124-135. https://doi.org/10.1108/17590831011055860

Nugroho, A. P., Hidayat, A., \& Kusuma, H. (2017). The influence of religiosity and self-efficacy on the saving behavior of the Islamic banks. Banks and Bank Systems, 12(3), 35-47. https://doi. org/10.21511/bbs.12(3).2017.03

Paul, J., Modi, A., \& Patel, J. (2016). Journal of Retailing and Consumer Services Predicting green product consumption using theory of planned behavior and reasoned action. Journal of Retailing and Consumer Services, 29, 123-134. https://doi.org/10.1016/j. jretconser.2015.11.006

Pookulangara, S., \& Natesan, P. (2010). Examining Consumers' channelmigration intention utilizing theory of planned behavior: a multigroup analysis. International Journal of Electronic Commerce Studies, 1(2), 97-116. Retrieved from http://www.academic-journals.org/ojs2/ index.php/ijecs/article/viewFile/919/58

Rackley, J. (2015). Marketing Analytics Roadmap: Methods, Metrics, and Tools, 168. Retrieved from https://books.google.com/ books?id=11YnCgAAQBAJ\&pgis $=1$

Rahab, \& Wahyuni, P. (2013). Predicting Knowledge Sharing Intention Based on Theory of Reasoned Action Framework : An Empirical Study on Higher Education Institution. American International Journal of Contemporary Research, 3(1), 138-147.

Shih, Y., \& Fang, K. (2004). The use of a decomposed theory of planned behavior to study Internet banking in Taiwan. Internet Research, 14(3), 213-223. https://doi.org/10.1108/10662240410542643

Sirgy, M. J. (1982). Self-concept in consumer behavior: A critical review. Journal of Consumer Research, 9(3), 287-300.

Soesilowati, E. S. (2011). Business opportunities for halal products in the global market: Muslim consumer behaviour and halal food consumption. Journal of Indonesian Social Sciences and Humanities, 3, 151-160. 
Taylor, S., \& Todd, P. A. (1995). Understanding information technology usage: A test of competing models. Information Systems Research.

IHTIFAZ - JIEFB https://doi.org/10.1287/isre.6.2.144

Thomson Reuters. (2018). State of The Global Islamic Economic : An Inclusive Ethical Economy. Retrieved from https://www. salaamgateway.com/en/story/Report_State_of_the_Global_Islamic_ Economy_201819-SALAAM06092018061914/

Vignoles, V. L., Regalia, C., Manzi, C., Golledge, J., \& Scabini, E. (2006). Beyond self-esteem: influence of multiple motives on identity construction. Journal of Personality and Social Psychology, 90(2), 308.

Vinzi, V. E., Chin, W. W., \& Henseler, J. (2010). Handbook of Partial Least Squares: Concepts, Methods and Applications. Handbook of Partial Least Squares. https://doi.org/10.1007/978-3-540-32827-8

Xiao, J., \& Wu, J. (2006). Applying the theory of planned behavior to retain credit counseling clients. In Proceedings of the Association for Financial Counseling and Planning Education, 91-100. Retrieved from http://tcainstitute.org/working_papers/wp65xiaowu.pdf 